とさられ遗憾なきまで御答へ下され硃に大島博士が最も新しい御話か下され厚く御禮が上げます實は先刻、 協會の事務長が私に申しま寸のに協會は來年三月博覽會を上野で開くから宜しく賴もといふことてありましたそ

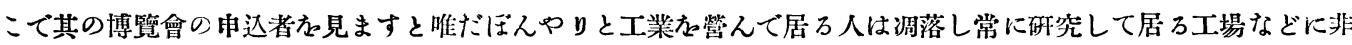
常に優勢であ万博覽會が來ても何事す仰しやら始どんどん出品なさります然万に在來のままにして居万工場は段

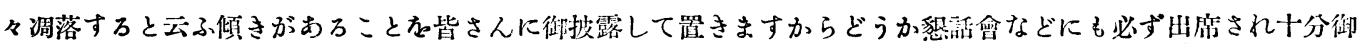
研究下されたら宜しいことと思つて居ります本夕御出席の御方は皆結整な御人達でありますから特に斯んなこと

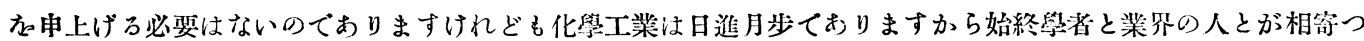

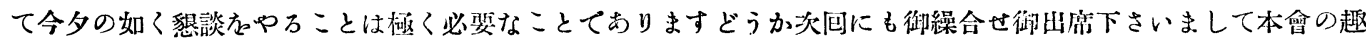
旨の微底するやう御同情方願したい次第でありますそれでは是れで散會いたします

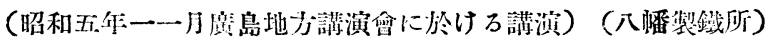

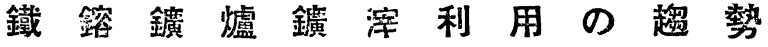 \\ 香 春 三樹 次
}

I. 繀諭

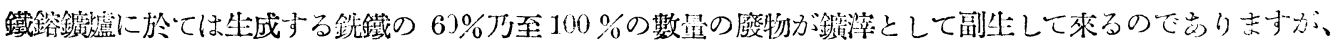

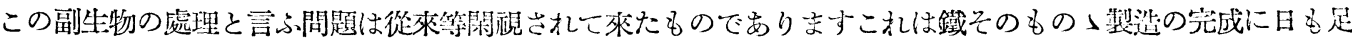

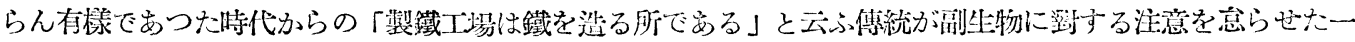

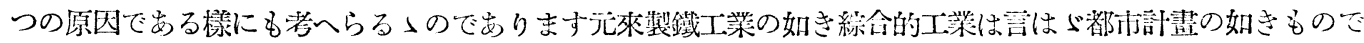

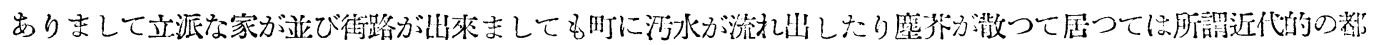

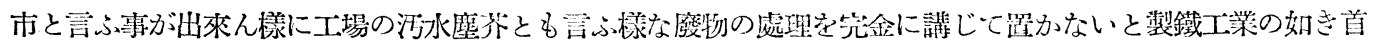

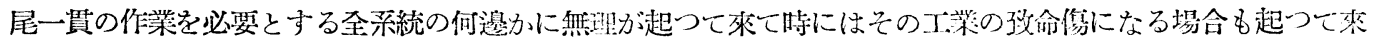
るものであります

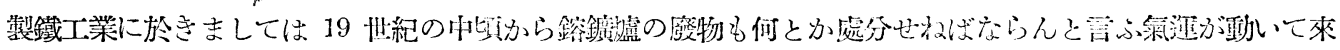

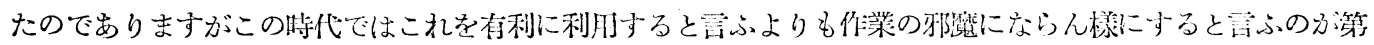

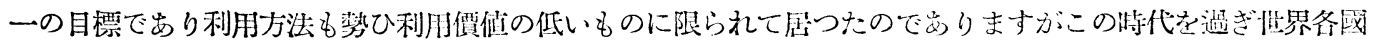

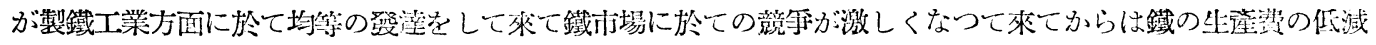

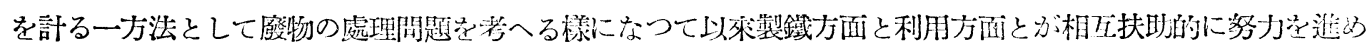

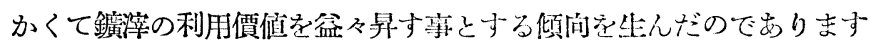

$$
\text { 第 一 表 }
$$

The production of Blast-FurnaceSlag in Japan.

Year

1925

1926

1927

1928

1929
Production. 598,000 tons 753,700 945,100

$1,047,600$ $1,148,800$

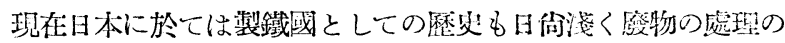
不完全に恢りて工場操作の障些を來寸が如き事は無いかの㦈に思

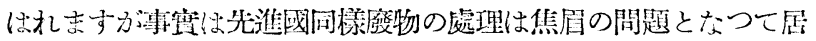

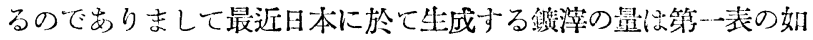

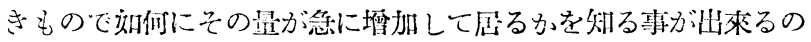
であります

世界各製鐵國の生成鑪滓肎銑鐵の $70 \%$ 平均と見るとき各成に於ける最近鑛漳生成量は第二表の如き數字を 示すのであります 
第 二 表

The amount of pig-iron \& blast-furnace slag in the world. (in 1928) Assuming the ammout of slag to be $70 \%$ of the pig-iron. name of country

U. S. A.

Germany

France

Grait Britain

Be!gium

Russia

Luxemburg

Saar-District

Japan

Checko

Canada

British India

Others

Total

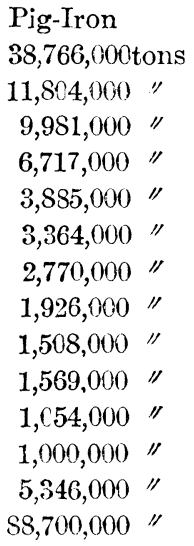

Slag 26,136,000tons $8,263,000$ " $6,987,000$ " $4,702,000$ " $2,720,000$ " $2,355,000$ " $1,939,000$ " $1,355,000$ " $1,055,600$ " $\mathbf{1 , 6 9 8 , 0 0 0 " ~}$ 738,000 " 700,000 " $3,742,000$ " $62,090,000$ "

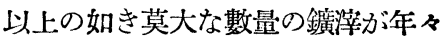
歲々生成して來るのでこの利用方法が 無けれはば結局この處理費用は次第に增 加して製鐵事業の癌となる事乡想像す る事が困䧼では無いと思ふのでありま す、では今日この畬㵏が如何なる方面 に利用されて庴るかと中しますと大約 第三表の燃きものであります

以上の利用方法を大别しますと

1. 上メント系利用方法

2. 碎不采利用方法

3. 雜

と㖵分寸る事が出來ると思ふのであり 六す

第一淩 鍍 滓 の 利 用

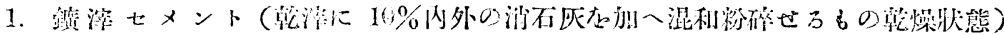

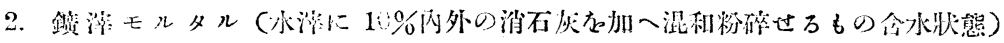

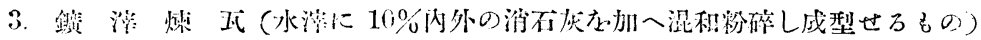

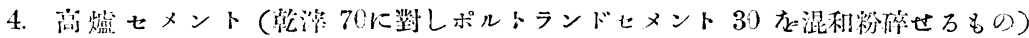

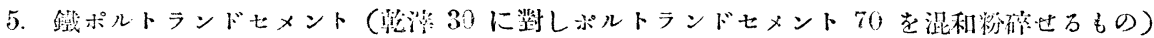

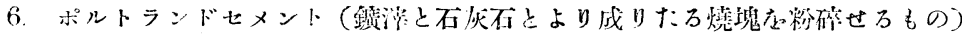

7. 路海バラ

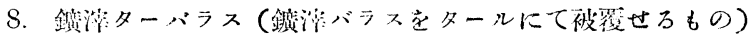

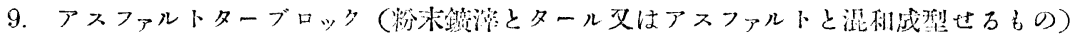

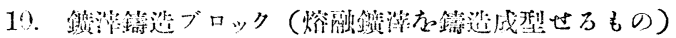

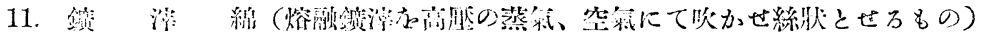

II. 它メント采利朋应沚

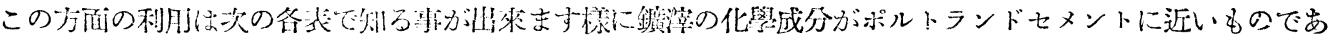

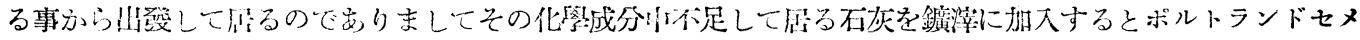

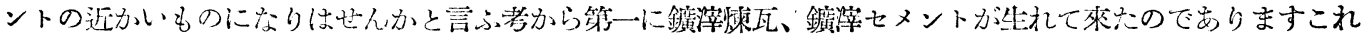

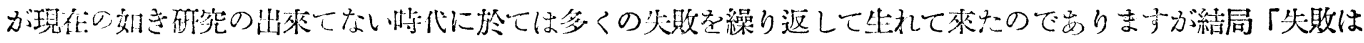
成功の母」とでも时しますかこの特代に今日の混合セメントに利用才る鑛荤の矿究がその緒に就いたのであり ます

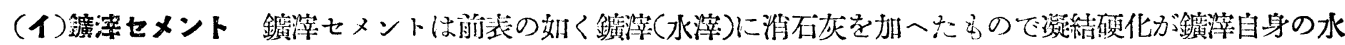
硬性に依るものでまりますので鑌滓も第四表の如く水硬性の强い特殊の化學成分を有するものに限られて居る 事を第一の不利の熙とし跒現在のセメントの代表者であるポルトランドセメントに比して品質が劣つて來ると 言ふ結果から今日の如き使用目的に依つての材料の選㣜と云ふ事が非常に面倒がられ全く䧸目的に高級セメン

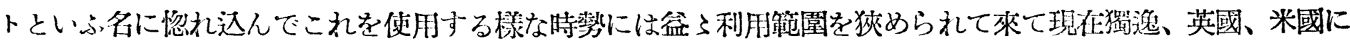


於てはこの慗造は殆しど中止され獨逸、英或に於ては高盧セメントに移り米或に於てはポルトランドセメント

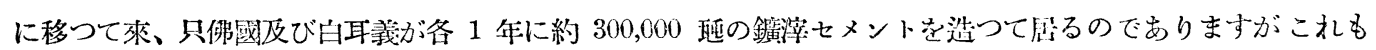

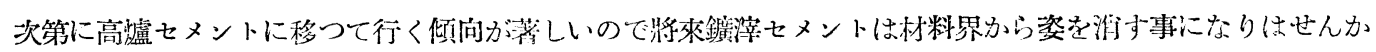
と思ふのであります

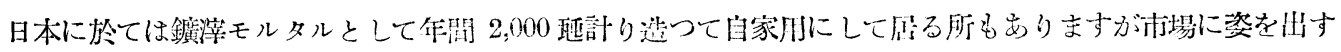
事は今の所一寸不可能かと思はる〉のであります

\section{第 四表}

Some example of the chemical composition of slag for "Slag-cement"

Country

Great Britain

Germany

Belgium

Spain

Switzeriand

France

America

Japan
$\mathrm{SiO}$.

30.00

30.72

32.51

32.90

26.88

31.65

32.20

351
$\mathrm{Al}_{2} \mathrm{O}_{3}$

28.60

16.40

13.19

13.25

24.12

17.00

15.50

11.7
$\mathrm{CaO}$

32.75

48.59

44.75

47.30

45.11

47.20

48.14

45.7

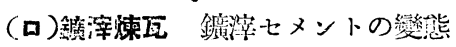

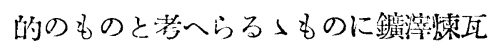
がありますこれは成型後相當日數硬化

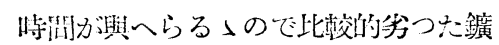
1.25

㳯でも十分な利用が出來場合に依つて

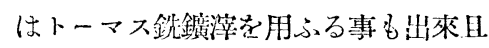
つ利月没储も比較的簡單で作業に容易 に罢宁さ礼る長所を持つて唇るので比

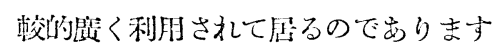

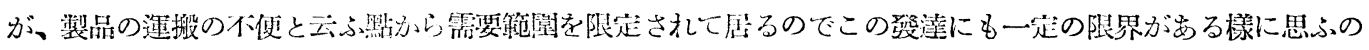

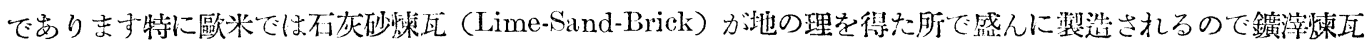

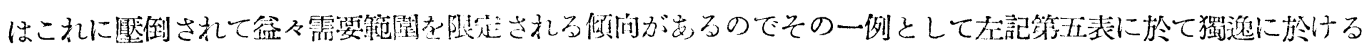

第 五. 表 A

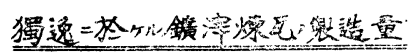

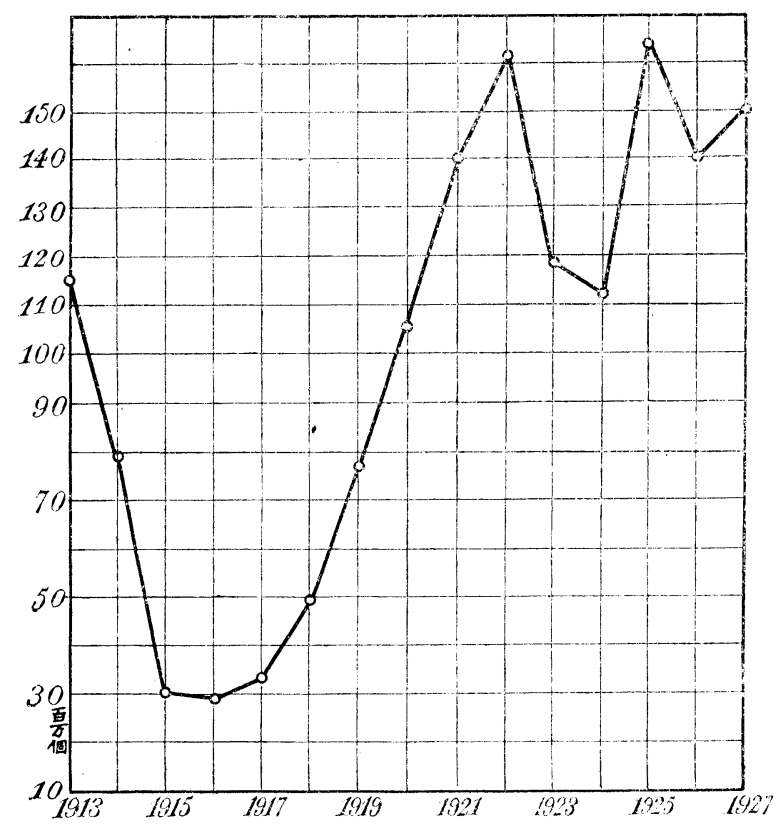

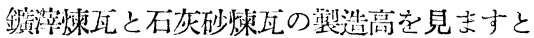
この倾向を知る事が出來るかと思ふのであ ります

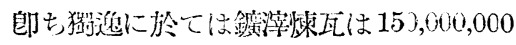

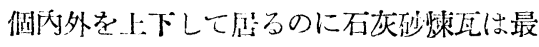

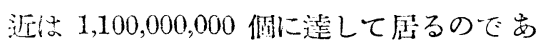
ります英、米、柳、白等に於きさしてもこ

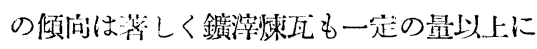
急激に延びる事は肘蜼で英、佛、自等は現 在の址灌 5 - 60,000,000 㑑で落ち着くので はないかと思はれます米國心教量は分りま せんが矢張り不灰砂煉瓦全盛の傾!可と思は 乣ます

日本に於ては昭和四年度に於て約 $60,000 ，$

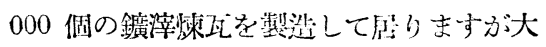
娟これでバランスが取机て局つてこれ以上 の增加は一寸困覲ではないかと思はれます

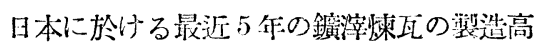


第 五 B 表

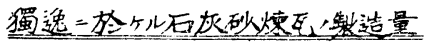

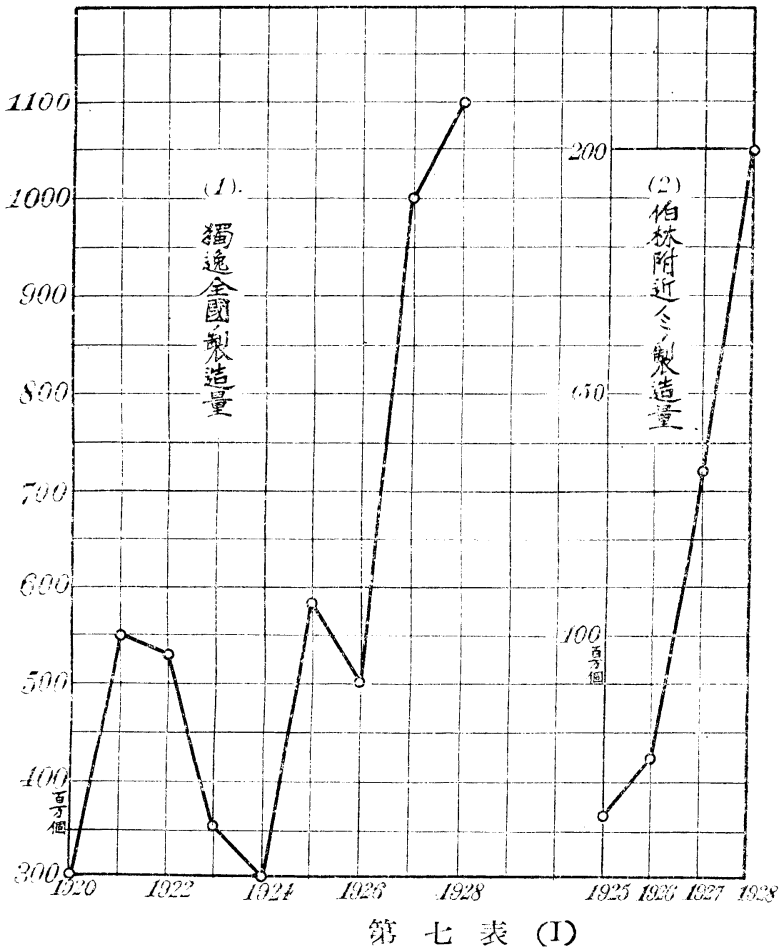

The chemical composition of blastfurnace-slags. (In Europe)

$\begin{array}{lcccr}\text { Name of works } & \mathrm{SiO}_{2} & \mathrm{Al}_{2} \mathrm{O}_{3} & \mathrm{CaO} & \mathrm{MgO} \\ \text { Friedrichwilhelmshiits } & 35.43 & 13.02 & 44.87 & 3.80 \\ \text { Hiittenwerke Vu!kan } & 33.86 & 15.30 & 40.11 & 2.71 \\ \text { Halberger Hiitte } & 34.20 & 21.00 & 39.62 & 3.87 \\ \text { Gutehoffnungshitte } & 32.64 & 9.70 & 46.62 & 3.87 \\ \text { Siphien Hiitte } & 32.00 & 13.45 & 43.68 & 2.09 \\ \text { Völklingen Hütte } & 31.30 & 17.10 & 42.63 & 3.98 \\ \text { Gelsenkirchener Hitte } & 35.66 & 15.80 & 43.40 & 3.43 \\ \text { Hiittenwerke Rheinhausen } & 34.02 & 15.15 & 45.01 & 3.51 \\ \text { Hüttenwerke Witkowitz } & 33.04 & 16.05 & 42.42 & 5.79 \\ \text { Glasgow Strrl works } & 34.84 & 11.70 & 47.18 & 3.65 \\ \text { Kockeril Steel Works } & 30.82 & 16.45 & 46.13 & 3.67\end{array}$

第 七 裴 (II)

The chemical composition of Japanese slag.

$\begin{array}{llllll}\text { No } & \mathrm{SiO}_{2} & \mathrm{Al}_{2} \mathrm{O}_{3} & \mathrm{CaO} & \mathrm{MgO} & \\ 1 & 34.22 & 14.93 & 45.44 & 3.89 & \mathrm{X} \\ 2 & 39.65 & 8.36 & 45.55 & - & \mathrm{X} \\ 3 & 35.1 & 11.7 & 45.7 & 3.8 & \\ 4 & 35.29 & 14.10 & 41.95 & 6.11 & \mathrm{X} \\ 5 & 35.28 & 14.50 & 46.11 & - & \\ 6 & 27.77 & 18.16 & 46.06 & - & \mathrm{X} \\ 7 & 34.74 & 16.65 & 43.95 & 1.95 & \\ 8 & 31.43 & 17.91 & 44.58 & 3.77 & \end{array}$

N. B. X-Slags which are used to make blast-furnace cement.
は第六表の如きものであります

第 宍 表

The amount of slag-brick made in Japan.

\begin{tabular}{ll} 
Year & \multicolumn{1}{c}{ Amount } \\
1925 & $44,000,000$ pieces \\
1926 & $27,000,000 " /$ \\
1927 & $28,700,000 "$ \\
1928 & $49,500,000 "$ \\
1929 & $61,000,000 "$
\end{tabular}

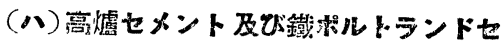

メント溜盧セメント文び鐵ポルトランド

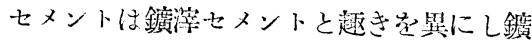
灌とポルトランドセメントを混和したもの

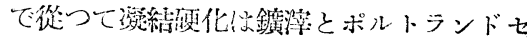

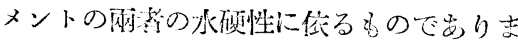

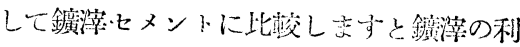

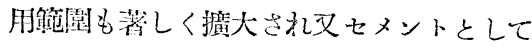
の諸性劕も現代の要求に合致するものとな りますし而ふも利用價值としては相當のも

のでありますので最近の傾向 では利朋し得る限りの鑛㵏を この種のセメントに向ける事 になつたのだ安ります

高罏セメントと鐵ポルトラ ンドセメントの名稻は鑌漳及 びポルトランドセメント三惹 の配合剖合の相違から來て居 りますが現在ではこの區別の 必要君認めない樣になつて來 て猲凞では Hüttenzement と云ふ名称で統一されれ英或に 於てはBlast-fumace Cement で統一され其他の國に於ても

"Blast-fumace Cement"

と云ふ意味の名䊈て統一され

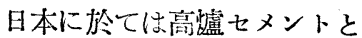
云ふ暺一名に霜者を含先樣に 
第 八 表

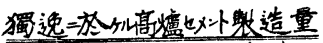

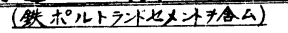

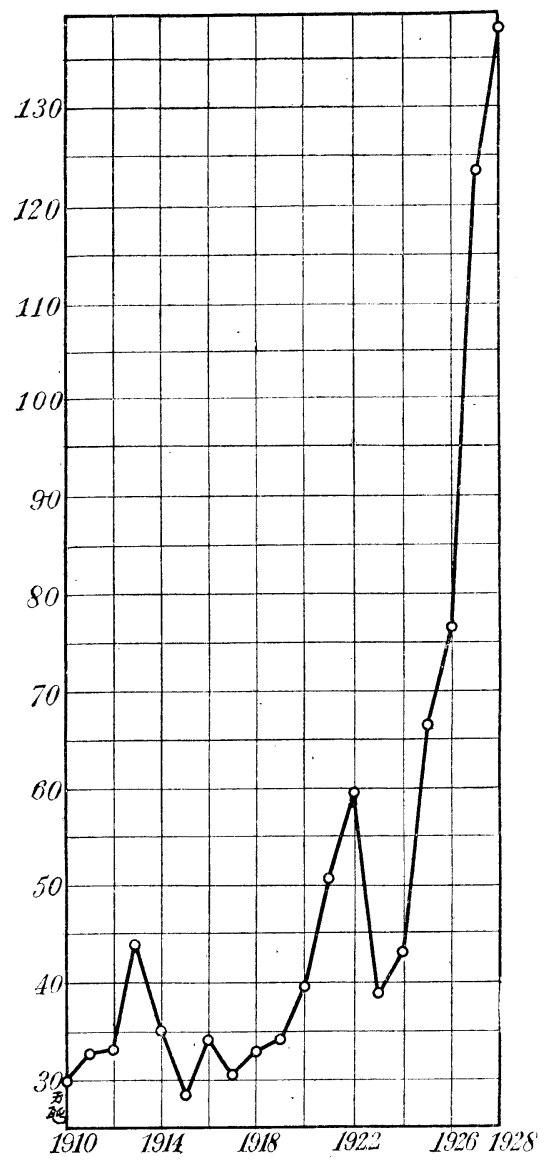

規定されて居ります

この種のセメントは最近各國に於て著しき增加を來たした のでありまして一例として獨逸に於けるこの種（高笽セメン ト及で鐵ポルトランドセメントを含めて高爐セメントと呼 ぶ）のセメントの生潼を示しますと籍八表の通りであります 批界主要國の高獹セメントの生黨は獨逸の $1,490,000$ 酗を 筆頭として佛國 500,000 饳（露國 250,000 迎）白耳義 200,000

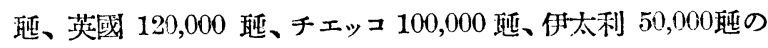
見當でありまして日本に於ては大嘈第九表の如き上昇を示し

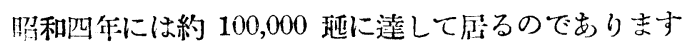

\section{第 九 表}

The production of blast-furnacec :ment in Japan.

$\begin{array}{cc}\text { Year } & \text { Production } \\ 1925 & 17,100 \text { tons } \\ 1926 & 24,350 " \\ 1927 & 27,590 " \\ 1928 & 78,550 " \\ 1929 & 100,800 "\end{array}$

（ニ)ポルトランドセメント これは鑛㳯の水硬性を利用し たものでなく單に石灰及び粘土の代用品として鑪㳯を利用し たものでせりますので鑛㳯の成分が均一でありさへすれば化 學减分に對しては面倒な條件はないのでありまして作業上燒 塊の燒成が比較的容易であると云ふ長所と原料が比傚的廉價 であると云ふ事から出發したもので混合セメントとして不適

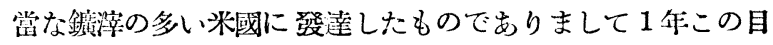

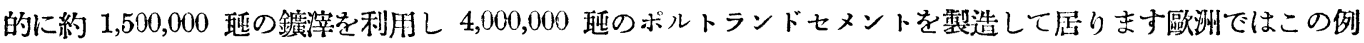
はない樣で僅か獨逸で高級セメント原料として注目されて居る程度であります

日本に於ては內及研究を進めて居る所がある樣に閆いて居りますが賽例はない樣に思はれます ポルトランドに利用しつ১ある鏬涬の成分の一例は第一○表の樣なものであります

$$
\text { 第 } \rightarrow O \text { 表 }
$$

Chemical composition of some of the American slag being used to make portlandcement.

$\begin{array}{lllrr}\text { No } & \mathrm{SiO}_{2} & \mathrm{Al}_{2} \mathrm{O}_{3} & \mathrm{CaO} & \mathrm{MgO} \\ 1 & 37.68 & 11.40 & 30.52 & 13.32 \\ 2 & 36.88 & 12.60 & 40.74 & 5.50 \\ 3 & 34.40 & 14.80 & 41.02 & 5.43 \\ 4 & 35.84 & 12.75 & 42.84 & 3.04\end{array}$

III. 碎石代用系利用方法 (䊯㳯バラス)

鑛漳を碎石代用品として利用する事は最 も原始的な方泆ではもりますが鑛滓の中に は煉瓦、セメントに使用する事の困難なも のが相當多量にあり而もこの方面に利用の

出來娘湲は碎石代用として理想的な狀態にありますのとこの利用設備が比較的簡單で大した費用を要せ奴點 から今でもこの方面に於ける利用がその數量に於ては最も多いのであります 
この利用方法は最も古い利用方法ではありますがこの利用は最近急激に增加したものでありまして交通の發 達に依る道路、鐵道及び混凝士構造の增加を主要なる原因と考へらるつのであります

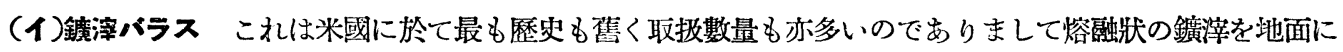
て徐々に放冷したものを掘り取つて破碎節別したもので道路、鐵道及び混凝土骨材として利用さるつのであり まして米國に於ては鑛㳯バラスにて 20 階建の建造物がありまして之れに 38,000 立方米の鑛漳バラスを利用 して居るのであります

この方面に於ける 利用は米國の年間 8,000,000 珽老筆頭にし圔逸 3,000,000、英國 2,000,000、佛或 1,500,000

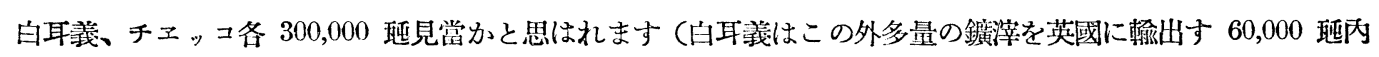
外？）日本に於ても比較的占くから利用されて居りましたが炤和四午には約 120,000 婳に達したのでありま †

$$
\text { 第一一表 }
$$

The production of Slag-Ballast in Japan

$\begin{array}{lc}\text { Year } & \text { Quantity } \\ 1925 & 48,000 \text { tons } \\ 1926 & 55,900^{\prime \prime} \\ 1927 & 64,600^{\prime \prime} \\ 1928 & 92,400^{\prime \prime} \\ 1929 & 118,600 "\end{array}$

（ロ）鑛滓ターパラス 前述の鑪㳯バラスを只バラスとして 利用する丈では曲がないのでありまして製鐵國であり同時に 石炭工業の國である英國では石炭工業の副生物コールタール を併用してターマカダムと云ふ鋪裝材料を造つたのでありま すこれは鈸㵏をタールで天婦羅にしたのでありまして簡易で 耐久力のある鋪裝材料が出來たのでありますこれは約 20 年 許りの歴史を有し好成績でありますので各國に探用されて來 たのでありまして將來交通と云ふ事が重大䅐される程益々發涬して來るものと思はれます特に從來揀炭材料に されて居つたピッチが樕炭が夜澧燃料に置換された結果ピッチをタールとしてその消化を道路の方面に見出す 事になりますのでタール使用の幥加に連れ鍍滓ターバラスも必然的に增加して來るものと考へられます

英國に於ては年間 1,500,000 䎲の鑛滓ターバラスを作り䍖逸 200,000 婳、佛國 300,000 㺷の數字を示すので あります

我國に於てもこの利用は八幡に於て大正一三年以降砢究され昭和三年にその製造を始められまして非常に好 成績を示して居りますので將來タールの利用方法として增加して來るものと思はれます

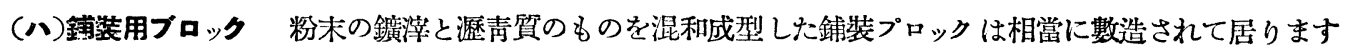

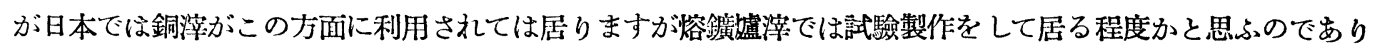
ます鋪裝用プロックとして愹融狀の鑛涬を鑄造し緩冷却をしたものがありますこれは獨逸で $35,000,000$ 個チ エッコでは 1,000,000 㮯瑞典、英或でも相當多量作られて居りますが日本に於ては試驗製作の 程度と思ふので むります

IV. 雜

其の他の利用方法として鋌滓綿がありますこれは數量としては大したものではありませんが利用價值として は相當高いものであります日本に於ては昭和四年度 850 珽の鈸滓綿を作つて居るのであります其他鑛滓を利用 して作つ太海綿狀保溫村等もありますが大し太量でもなく將來も大して發達する樣にも思はれません

$$
\mathrm{V} \text {. 結 論 }
$$

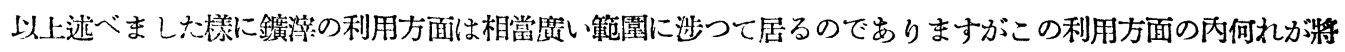
來最も存利な利用方法であるかと言ふ事は地理的關係に左右される事が多いのでありまして第一に考へねばな 


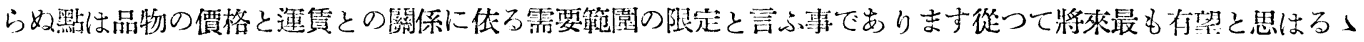
のに運貢が製品に街して大なる囚數とならん樣な利用價値の高い品物に力を注ぐのが现在の倾向であり又將來

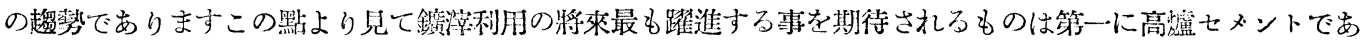

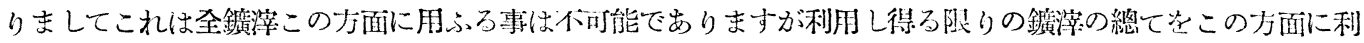

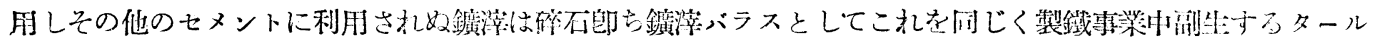
と關絡せしめて鋮裝用ターバラスとする事であると估ずるものであります

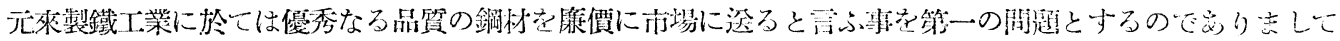

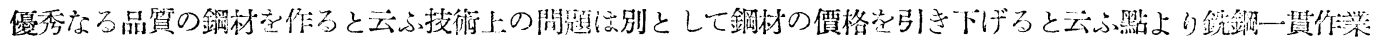

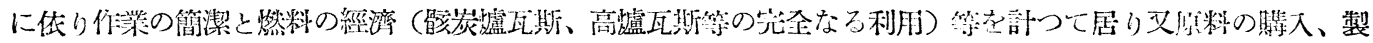

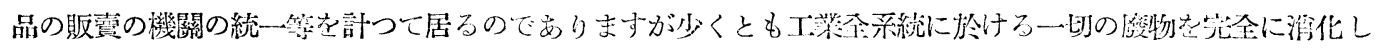

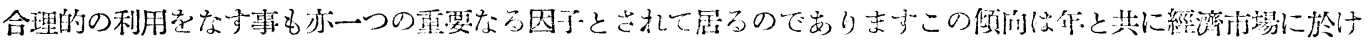

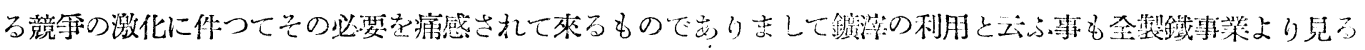

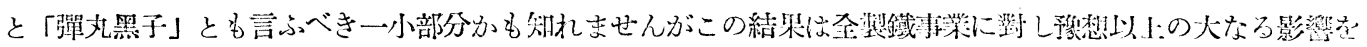
付寸るものである事を切触に感じて篔るものであります

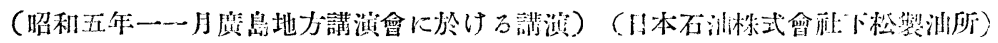

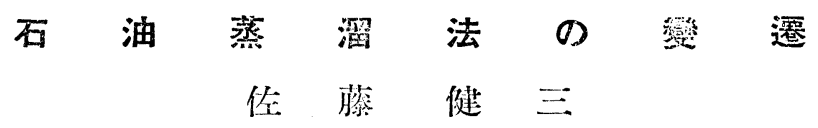

本問題に先立ちて石油は如何にして作られ又如何なる用途があるかは漓面により御承知愿し度いのでありま

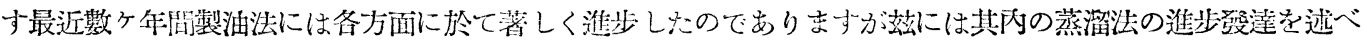

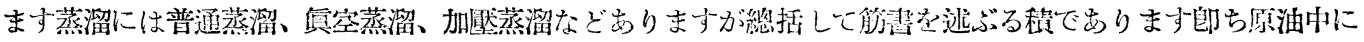
含有せらる〉各種炭化水素を先づ蒸溜に依り分つのでありま寸蒸溜法の理想は各溜出泊が㻰然と分れる事であ ります然るに不油中には種々の系統の炭化水素があり又同系統のものでも互に沸腾點の近きものである故に其

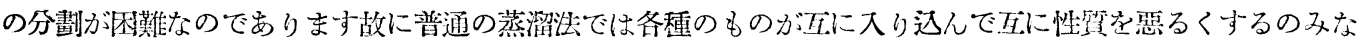

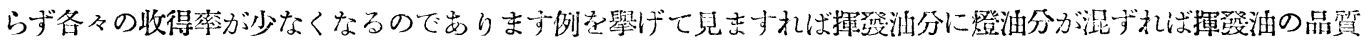
を惡るくするのであります又燈油の方から見れば揮發油か混しつつて引火點が低いとか义は其下の輕油分がはい

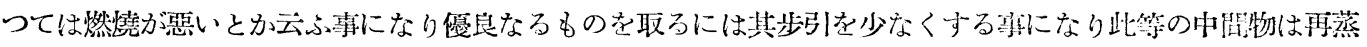

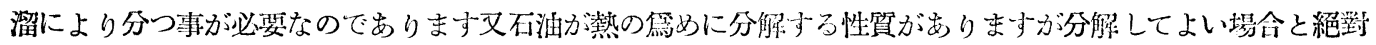
に惡い場合とあります次に燃料でありますがこれは石油製造には大なる經費の一つであります之を改善するの が丈一つの問題であります其の他稙々ありますが追つて中上げます

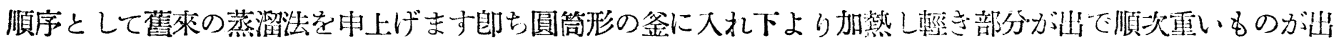

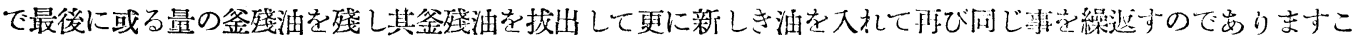

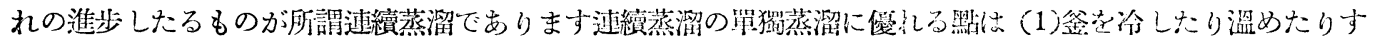

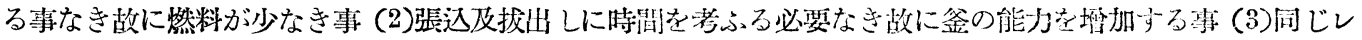
トルトパイプよりは常に同じ油が出る故に溜出油の混合少なき事、4)釜內泊が一定のレベルにある故單獨蒸溜 